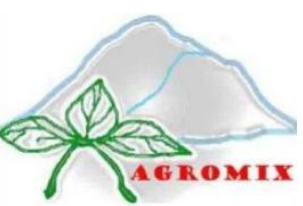

\title{
AGROMIX
}

Jurnal IImiah Fakultas Pertanian, Universitas Yudharta Pasuruan pISSN (Print): 2085-241X; eISSN (Online): 2599-3003

Website: https://jurnal.yudharta.ac.id/v2/index.php/agromix

\section{Inovasi teknologi budidaya bawang dayak (Eleutherine palmifolia Merr) untuk meningkatkan produktivitas dan analisis kelayakan ekonomi}

\author{
Cultivation technology innovation of dayak onion (Eleutherine palmifolia Merr) to increase productivity and economic \\ feasibility analysis
}

\author{
Titin Apung Atikah ${ }^{1 *}$, Tatik Wardiyati ${ }^{2}$, Ellis Nihayati ${ }^{2}$, Saputera ${ }^{1}$, Doppy Roy Nendissa ${ }^{3}$ \\ ${ }^{1}$ Fakultas Pertanian, Universitas Palangka Raya, Kalimantan Tengah \\ ${ }^{2}$ Fakultas Pertanian, Universitas Brawijaya, Malang, Jawa Timur \\ ${ }^{3}$ Fakultas Pertanian, Universitas Nusa Cendana, Kupang, Nusa Tenggara Timur \\ *E-mail korespondensi: titinapungatikah@ymail.com
}

\section{Article History}

Received : October 26, 2020

Accepted : February 02, 2021

Published : March 30, 2021

Keyword

Farming analysis;

Eleutherine palmifolia Merr;

NPK; chicken manure;

productivity

\section{ABSTRACT}

Dayak onions (Eleutherine palmifolia Merr) are a potential commodity that has many health benefits, so it has a high economic value. However, this Dayak onion plant has not received much attention in cultivation technology, especially fertilization. So far, this onion has grown relying on nature, while the land has diminished its fertility. This study tested a combination of chicken manure and NPK fertilizer to obtain the optimal composition to increase the productivity of Dayak onions. This study used a factorial randomized block design with 3 replications. The first factor consists of the treatment of chicken manure (01 = control, $02=10$ ton.ha- 1 and $03=20$ ton.ha-1). The second factor consists of NPK fertilizer $(\mathrm{K} 1=$ control, $\mathrm{K} 2=100 \mathrm{~kg} \cdot \mathrm{ha}-1 \mathrm{Urea}+150 \mathrm{~kg} \cdot \mathrm{ha}-1 \mathrm{SP} 36+200 \mathrm{~kg} \cdot \mathrm{ha}-1 \mathrm{KCl}, \mathrm{K} 3=200 \mathrm{~kg} \cdot \mathrm{ha}-1$ Urea + $150 \mathrm{~kg} \cdot \mathrm{ha}-1 \mathrm{SP} 36+200 \mathrm{~kg} \cdot \mathrm{ha}-1 \mathrm{KCl}$, and K4 = $300 \mathrm{~kg} \cdot \mathrm{ha}-1$ Urea $+150 \mathrm{~kg} \cdot \mathrm{ha}-1 \mathrm{SP} 36+200$ kg.ha-1 KCl). The results showed that there was an interaction effect between the composition of chicken manure and NPK on the number of leaves, fresh weight of tubers, and dry weight of tubers per clump but did not affect the growth of plant height. The yield of Dayak bulbs of $62.60 \mathrm{~g} /$ clump was obtained in the composition of chicken manure of 20 tonnes.ha-1 with an NPK of $200 \mathrm{~kg}$.ha-1 Urea $+150 \mathrm{~kg}$.ha-1 SP $36+200 \mathrm{~kg}$.ha- $1 \mathrm{KCl}$. From an economic perspective, the composition is very efficient and feasible, which is indicated by $R / C>1$, namely 5.75 , which means that with a certain unit cost, it can get 5.75 times the revenue.

\section{Riwayat Artikel \\ Dikirim : 26 Oktober 2020 \\ Disetujui : 02 Pebruari 2021 \\ Diterbitkan : 30 Maret 2021}

\section{Kata Kunci}

Analisis usahatani;

Eleutherine palmifolia Merr;

NPK; pupuk kandang ayam; produktivitas

\section{ABSTRAK}

Bawang dayak (Eleutherine palmifolia Merr) merupakan salah satu komoditi berpotensi yang memiliki banyak manfaat bagi kesehatan, sehingga memiliki nilai ekonomis yang tinggi. Namun, tanaman bawang dayak ini belum banyak mendapat perhatian dalam teknologi budidaya, terutama pemupukan. Selama ini bawang ini tumbuh mengandalkan pada alam, sedangkan lahan makin berkurang kesuburannya. Studi ini menguji kombinasi kotoran ayam dan pupuk NPK guna mendapat komposisi yang optimal untuk meningkatkan produktivitas bawang dayak. Penelitian ini menggunakan Rancangan Acak Kelompok faktorial dengan 3 ulangan. Faktor I terdiri atas perlakuan pupuk kotoran ayam $(\mathrm{O} 1=$ kontrol, $\mathrm{O} 2=10$ ton.ha-1 dan $03=20$ ton.ha-1). Faktor II terdiri atas takaran pupuk NPK (K1= kontrol, K2 $=100 \mathrm{~kg} \cdot \mathrm{ha}-1$ Urea + 150 kg.ha-1 SP $36+200$ kg.ha-1 KCl, K3= 200 kg.ha-1 Urea + 150 kg.ha-1 SP $36+200$ kg.ha-1 $\mathrm{KCl}$, dan K4= $300 \mathrm{~kg} \cdot \mathrm{ha}-1$ Urea $+150 \mathrm{~kg}$.ha-1 SP $36+200 \mathrm{~kg}$.ha-1 KCl). Hasil penelitian menunjukkan adanya efek interaksi antara komposisi pupuk kotoran ayam dan NPK terhadap jumlah daun, bobot segar umbi dan bobot kering umbi per rumpun tetapi tidak berpengaruh terhadap pertumbuhan tinggi tanaman. Hasil umbi bawang dayak sebesar $62,60 \mathrm{~g} /$ rumpun diperoleh pada komposisi pupuk kotoran ayam sebesar 20 ton.ha-1 dengan NPK sebesar 200 kg.ha-1 Urea + 150 kg.ha-1 SP $36+200$ kg.ha-1 $\mathrm{KCl}$. Secara ekonomi, komposisi tersebut sangat efisien dan layak yang ditunjukkan oleh $\mathrm{R} / \mathrm{C}>1$ yaitu 5,75 artinya dengan satuan biaya tertentu mampu mendapatkan penerimaan 5,75 kali lipat.

Sitasi: Atikah, T. A., Wardiyati, T., Nihayati, E., Saputera, S., \& Nendissa, D. R. (2021). Inovasi teknologi budidaya bawang dayak (Eleutherine palmifolia Merr) untuk meningkatkan produktivitas dan analisis kelayakan ekonomi. Agromix, 12(1), 39-46. https://doi.org/10.35891/agx.v12i1.2331 


\section{PENDAHULUAN}

Bawang dayak (Eleutherine palmifolia Merr.) dikenal sebagai salah satu jenis tanaman obat yang banyak ditemui di Kalimantan Tengah. Umumnya masyarakat dayak menjadikan tanaman ini sebagai obat berbagai penyakit (Pusat Studi Biofarmaka LPPM IPB, 2013). Senyawa Eleutherine pada umbi bawang dayak merupakan senyawa yang hanya dimiliki spesies tanaman ini yang secara empiris dan klinis telah diteliti manfaatnya untuk mengobati bermacammacam jenis penyakit serta sebagai immunostimulant untuk mengoptimalkan imunitas tubuh (Nurcahyawati dkk., 2017; Bahtiar, A., \& Annisa, 2018; Arwati dkk., 2018; Harlita \& Oedjijono, 2018; Poerwosusanta, dkk., 2019; Fransira dkk., 2019; Yuanita dkk., 2019; Atikah, 2020; Kamarudin, dkk., 2020). Hasil panen petani yang masih terbatas karena belum adanya teknologi budidaya yang memadai serta rendahnya kandungan unsur hara di dalam tanah menyebabkan tanaman bawang dayak perlu mendapat perhatian dalam pengembangannya melalui penerapan teknologi budidaya misalnya penerapan teknologi pemupukan spesifik lokasi.

Pemupukan merupakan salah satu faktor penentu dalam upaya meningkatkan hasil tanaman. Pupuk yang digunakan sesuai anjuran diharapkan dapat memberikan hasil yang secara ekonomi menguntungkan (Napitupulu \& Winarto, 2010). Agar pertumbuhan dan hasil umbi bawang dayak lebih tinggi maka pertumbuhan harus cepat dan optimal. Tanaman perlu pupuk NPK sebagai sumber hara untuk proses pertumbuhannya (Gardner dkk., 1985, Lestari \& Palobo, 2019; Rambe dkk., 2020). Aplikasi pupuk NPK dalam jumlah cukup dan berimbang akan berpengaruh terhadap pertumbuhan dan hasil umbi (Jaya, 1994; Purba, 2014; Al-juthery, \& Al-Shami, 2019; Krestini, dkk., 2020).

Demikian pula, manfaat penambahan pupuk kotoran ayam diharapkan mampu mengatasi kendala tanah yang dominan berpasir dengan kemampuan menahan air relatif rendah, $\mathrm{pH}$ masam dan kandungan unsur hara rendah. Pupuk kotoran ayam memberikan pengaruh terhadap sifat fisik dan kimia tanah (Ghaffoor dkk., 2003; Candra, 2019; Hilwa dkk., 2020; Kriswantoro dkk., 2020; Deanti dkk., 2020; Iqbal dkk., 2020 ) melalui perbaikan struktur tanah, meningkatkan daya serap tanah berpasir terhadap air dan sumber hara bagi tanaman (Rosmarkam \& Yuwono, 2002), serta meningkatkan populasi mikroorganisme tanah dan menunjang pertumbuhan akar (Shareen dkk., 2007).

Berdasarkan uraian di atas, untuk mendapatkan pertumbuhan dan hasil umbi bawang dayak yang optimal perlu ditentukan komposisi pupuk kotoran ayam dan NPK yang sesuai dengan kebutuhan tanaman serta kondisi agroekosistem setempat. Penelitian ini bertujuan untuk mendapatkan komposisi optimal pupuk kotoran ayam dan NPK untuk meningkatkan produktivitas umbi bawang dayak serta analisis usahanya.

\section{METODE}

\section{Tempat pelaksanaan}

Penelitian ini dilaksanakan di Screen house, berlokasi di kota Palangka Raya, Provinsi Kalimantan Tengah, Indonesia.

\section{Alat dan bahan}

Alat dan Bahan yang digunakan terdiri : umbi bibit bawang dayak varietas lokal, polybag ukuran $40 \times 40 \mathrm{~cm}$, tanah sebagai media tanam dengan kandungan $\mathrm{N}$-total 0,33\%, P-Bray 13,94 mg.kg-1, K 0,02 me/100 g, pH tanah 4,8 dengan tekstur tanah lempung berpasir. Urea sebagai sumber $\mathrm{N}, \mathrm{SP} 36$ sebagai sumber $\mathrm{P}, \mathrm{KCl}$ sebagai sumber $\mathrm{K}$ dan pupuk kotoran ayam. Bahan tanam (umbi bibit) yang digunakan memiliki berat \pm 6-10 g/umbi. Kemudian umbi dipotong menjadi dua bagian yaitu umbi bagian atas (termasuk bagian daun) dan umbi bagian bawah (termasuk bagian akar). Pemotongan umbi dapat dilakukan dengan menyisakan $\pm 10 \mathrm{~cm}$ yang diukur dari ujung daun. Sebelum ditanam umbi direndam \pm 3 menit pada larutan fungisida, kemudian ditiriskan hingga kering. Umbi bibit kemudian ditanam ke dalam polybag yang sudah berisi media tanah dengan cara menyisakan sedikit bagian umbi di permukaan tanah.

\section{Rancangan percobaan}

Penelitian menggunakan Rancangan Acak Kelompok Faktorial dengan 3 ulangan. Faktor I terdiri atas perlakuan pupuk kotoran ayam (O1= kontrol, $\mathrm{O} 2=10$ ton.ha ${ }^{-1}$ dan $\mathrm{O} 3=20$ ton.ha $\left.{ }^{-1}\right)$. Faktor II terdiri atas takaran NPK (K1=kontrol, K2= 100 kg.ha-1 Urea $+150 \mathrm{~kg} \cdot \mathrm{ha}^{-1} \mathrm{SP} 36+200 \mathrm{~kg} \cdot \mathrm{ha}^{-1} \mathrm{KCl}, \mathrm{K} 3=200 \mathrm{~kg} \cdot \mathrm{ha}^{-1}$ Urea $+150 \mathrm{~kg} \cdot \mathrm{ha}^{-1} \mathrm{SP} 36+200 \mathrm{~kg} \cdot \mathrm{ha}^{-1}$ $\mathrm{KCl}, \mathrm{K} 4=300 \mathrm{~kg} \cdot \mathrm{ha}^{-1}$ Urea $\left.+150 \mathrm{~kg} \cdot \mathrm{ha}^{-1} \mathrm{SP} 36+200 \mathrm{~kg} \cdot \mathrm{ha}^{-1} \mathrm{KCl}\right)$. 

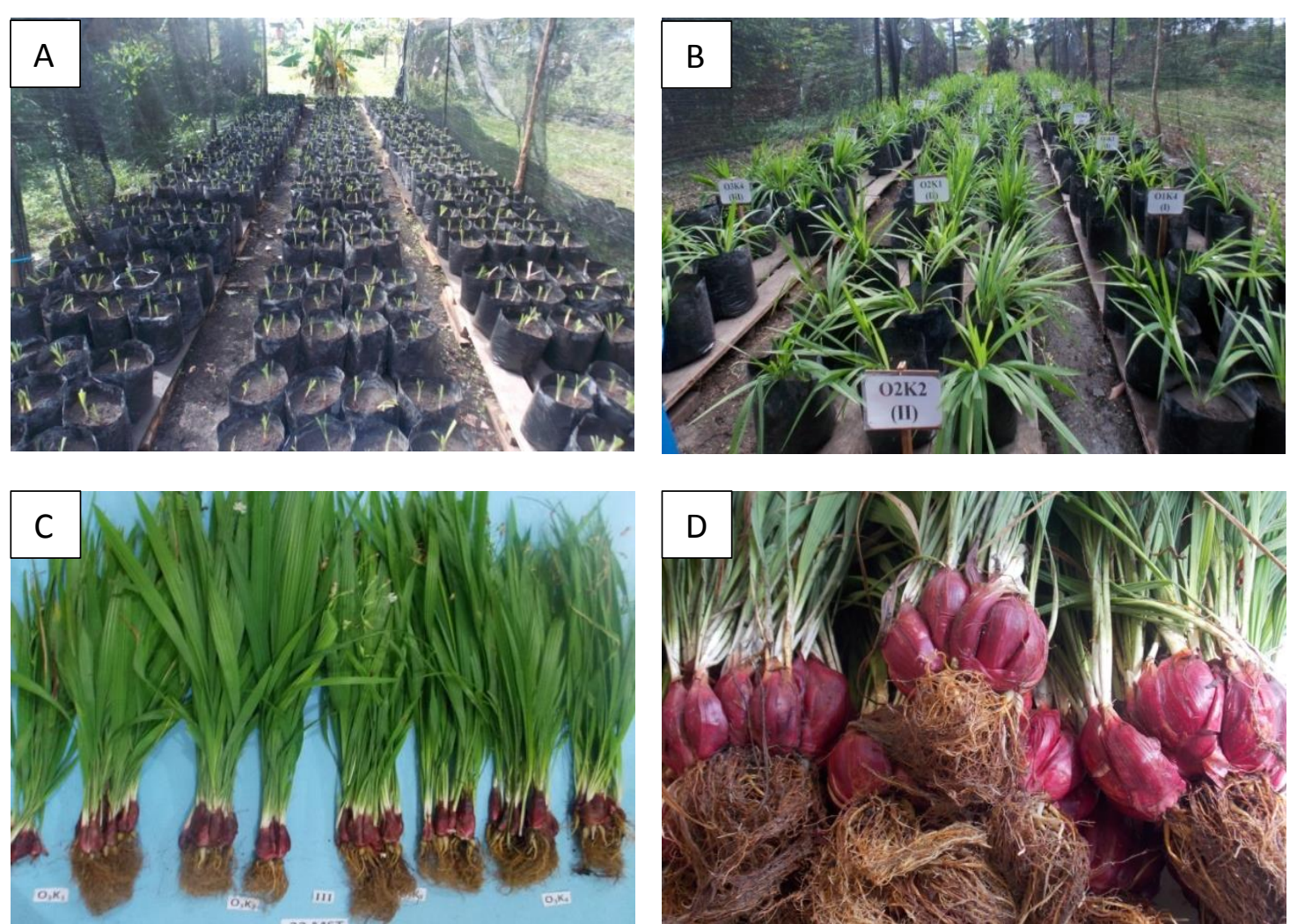

Gambar 1. Bawang dayak (Eleutherine palmifolia Merr.) A) Awal tanam , B) Tanaman umur 18 mst, C) Perbandingan perlakuan tanaman umur 20 mst, dan D) Hasil panen bawang dayak

Pengamatan non-destruktif dilakukan pada tanaman umur 10, 14, 18, 20 dan 22 mst terhadap parameter tinggi tanaman dan jumlah daun umur 20 mst. Tinggi tanaman diukur dari permukaan tanah hingga ke ujung tanaman tertinggi dengan menggunakan alat ukur (penggaris).Jumlah daun per rumpun dihitung terhadap daun yang berwarna hijau dan membuka sempurna. Pengamatan destruktif dilakukan pada saat panen yaitu pada tanaman umur 20 mst terhadap bobot segar umbi dan bobot kering umbi per rumpun. Hasil diamati dengan menimbang bobot segar umbi dan bobot kering umbi per rumpun.

\section{Analisa data}

Data yang diperoleh dianalisis menggunakan analisis ragam (ANOVA). Pengujian dilakukan dengan menggunakan uji F pada tingkat $5 \%$.Bila terjadi perbedaan signifikan antara perlakuan dilanjutkan dengan uji LSD pada tingkat $5 \%$.

\section{HASIL DAN PEMBAHASAN}

Parameter pertumbuhan yang diamati meliputi tinggi tanaman dan jumlah daun. Aplikasi pupuk kotoran ayam dan NPK tidak berpengaruh terhadap pertumbuhan tinggi tanaman tetapi berpengaruh nyata terhadap jumlah daun. Perlakuan pupuk kotoran ayam secara tunggal dengan takaran sebesar 20 ton.ha-1 mampu meningkatkan tinggi tanaman (Tabel 1), sedangkan perlakuan penambahan pupuk kotoran ayam dan NPK pada tanaman umur 20 mst mampu meningkatkan jumlah daun tanaman bawang dayak (Gambar 1).

Tabel 1.Rerata tinggi tanaman bawang dayak pada setiap perlakuan

\begin{tabular}{|c|c|c|c|c|c|}
\hline \multirow[t]{2}{*}{ Perlakuan } & \multicolumn{5}{|c|}{ Tinggi tanaman pada umur pengamatan (mst) } \\
\hline & 10 & 14 & 18 & 20 & 22 \\
\hline \multicolumn{6}{|c|}{ kotoran ayam } \\
\hline 01 & 44,61 & 47,55 & $49,75^{\mathrm{a}}$ & $50,85^{\mathrm{a}}$ & $50,73^{a}$ \\
\hline $\mathrm{O} 2$ & 47,34 & 51,33 & $53,61^{b}$ & $55,16^{\mathrm{b}}$ & $55,01^{b}$ \\
\hline $\mathrm{O} 3$ & 45,68 & 49,53 & $54,15^{b}$ & $57,09^{b}$ & $56,84^{b}$ \\
\hline BNT 5\% & $\operatorname{tn}$ & tn & 3,21 & 3,04 & 3,05 \\
\hline \multicolumn{6}{|c|}{ NPK } \\
\hline K1 & 47,01 & 50,83 & 53,28 & 55,08 & 54,81 \\
\hline $\mathrm{K} 2$ & 45,94 & 48,90 & 52,62 & 53,65 & 53,45 \\
\hline K3 & 43,78 & 48,43 & 51,37 & 52,87 & 52,77 \\
\hline K4 & 46,77 & 49,71 & 52,74 & 55,88 & 55,75 \\
\hline BNT 5\% & tn & $\mathrm{tn}$ & tn & tn & tn \\
\hline
\end{tabular}


Keterangan: Bilangan yang didampingi huruf yang sama pada baris dan kolom yang sama tidak berbeda nyata pada uji BNT 5\%; $\mathrm{mst}=$ minggu setelah tanam, $\mathrm{O} 1=$ tanpa kotoran ayam (kontrol) $; \mathrm{O}_{2}=10$ ton.ha- ${ }^{-1} ; \mathrm{O} 3=20$ ton.ha $\mathrm{han}^{-1} \mathrm{~K} 1=\operatorname{tanpa}$ NPK (kontrol) ; K2 = 100 kg.ha-1 urea $+150 \mathrm{~kg} \cdot \mathrm{ha}^{-1} \mathrm{SP}-36+200 \mathrm{~kg} \cdot \mathrm{ha}^{-1} \mathrm{KCl} ; \mathrm{K} 3=200 \mathrm{~kg} \cdot \mathrm{ha}^{-1} \mathrm{Urea}+150 \mathrm{~kg} \cdot \mathrm{ha}^{-1} \mathrm{KCl}$ dan K4 = $300 \mathrm{~kg} \cdot \mathrm{ha} \mathrm{a}^{-1} \mathrm{Urea}+150 \mathrm{~kg} \cdot \mathrm{ha}^{-1} \mathrm{SP} 36+200 \mathrm{~kg} \cdot \mathrm{ha}^{-1} \mathrm{KCl}$.

Hasil analisis tanah awal menunjukkan bahwa $\mathrm{pH}$ tanah tergolong masam dengan $\mathrm{N}$-total dan $\mathrm{P}$-tersedia tergolong sedang, unsur K sangat rendah dengan tekstur tanah didominasi pasir (Nugroho \& Firmansyah, 2007). Fraksi pasir berkorelasi negatif terhadap kapasitas tanah menahan air (Salter dkk., 1966). Penambahan pupuk kotoran ayam secara tunggal dan kombinasi mampu meningkatkan pertumbuhan tinggi tanaman dan jumlah daun hal ini karena selain dapat meningkatkan unsur hara, pupuk kotoran ayam juga mampu memperbaiki struktur tanah dan meningkatkan daya serap tanah berpasir terhadap air (Rosmarkam \& Yuwono, 2002) serta mampu meningkatkan populasi mikroorganisme dan perbaikan rhizosper perakaran (Shireen dkk., 2007). Hasil bawang merah meningkat seiring meningkatnya aplikasi pupuk kotoran ayam (Sharma dkk., 2003).

Perlakuan penambahan pupuk kotoran ayam 20 ton.ha-1 dan $200 \mathrm{~kg} \cdot \mathrm{ha}^{-1}$ urea $+150 \mathrm{~kg} \cdot \mathrm{ha}^{-1} \mathrm{SP}-36+200 \mathrm{~kg} \cdot \mathrm{ha}^{-1} \mathrm{KCl}$ (O3K3) pada umur 20 mst menunjukkan jumlah daun lebih tinggi namun tidak berbeda nyata dengan O3K2 dan O3K4 (Gambar 2). Hal ini menunjukkan adanya respon tanaman akibat penambahan takaran pupuk kotoran ayam dan NPK. Peningkatan tinggi tanaman akan diiringi dengan peningkatan jumlah daun akibat penambahan unsur hara makro dan mikro yang terkandung di dalam pupuk. Ditambahkan oleh Aliya dkk. (2007) bahwa peningkatan aplikasi pupuk NPK akan meningkatkan parameter pertumbuhan tanaman bawang merah.

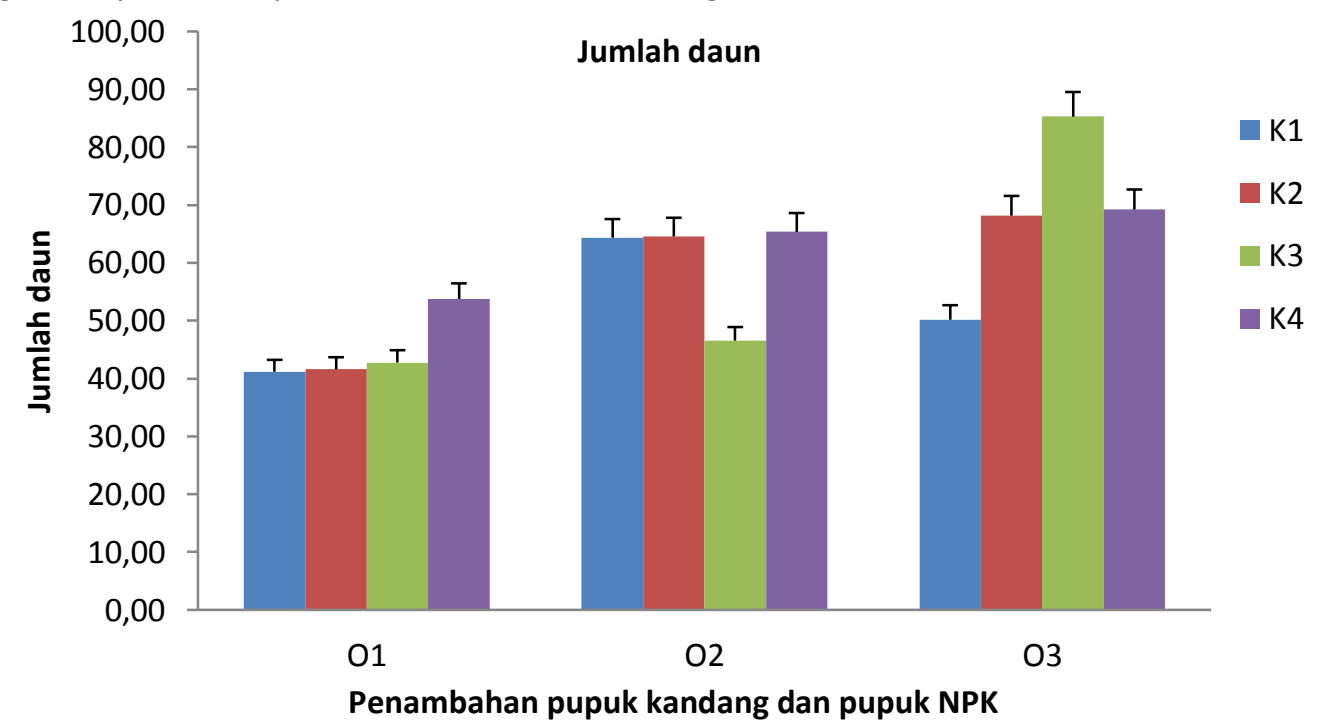

Gambar 2. Jumlah daun tanaman bawang dayak dari penambahan komposisi pupuk kotoran ayam dan NPK

Parameter hasil tanaman bawang dayak yang diamati yaitu bobot segar umbi dan bobot kering umbi. Berdasarkan hasil analisis ragam menunjukkan bahwa penambahan pupuk kotoran ayam dan NPK memberikan pengaruh interaksi terhadap peningkatan bobot segar umbi dan bobot kering umbi. Perlakuan komposisi pupuk kotoran ayam sebesar 20 ton.ha-1 dengan $200 \mathrm{~kg} \cdot \mathrm{ha}^{-1}$ Urea $+150 \mathrm{~kg} \cdot \mathrm{ha}^{-1} \mathrm{SP} 36+200 \mathrm{~kg} \cdot \mathrm{ha}^{-1} \mathrm{KCl}$ (O3K3) menunjukkan perbedaan signifikan dengan perlakuan lainnya dalam penambahan bobot segar umbi (Gambar 3a) maupun bobot kering umbi per rumpun (Gambar 3b).

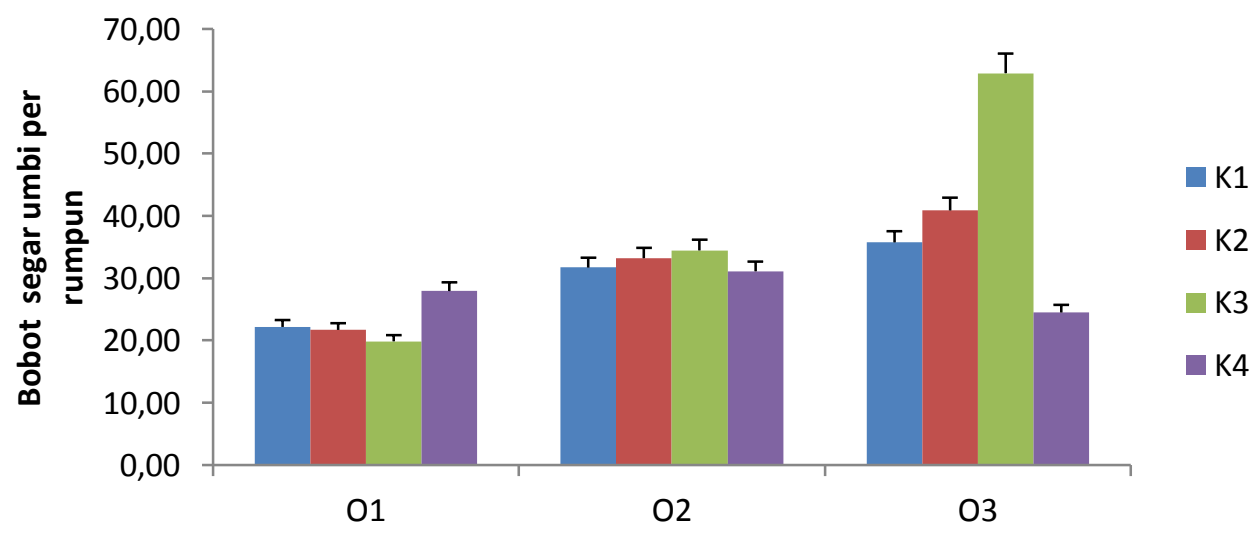

Perlakuan penambahan pupuk kandang dan NPK

(A) 


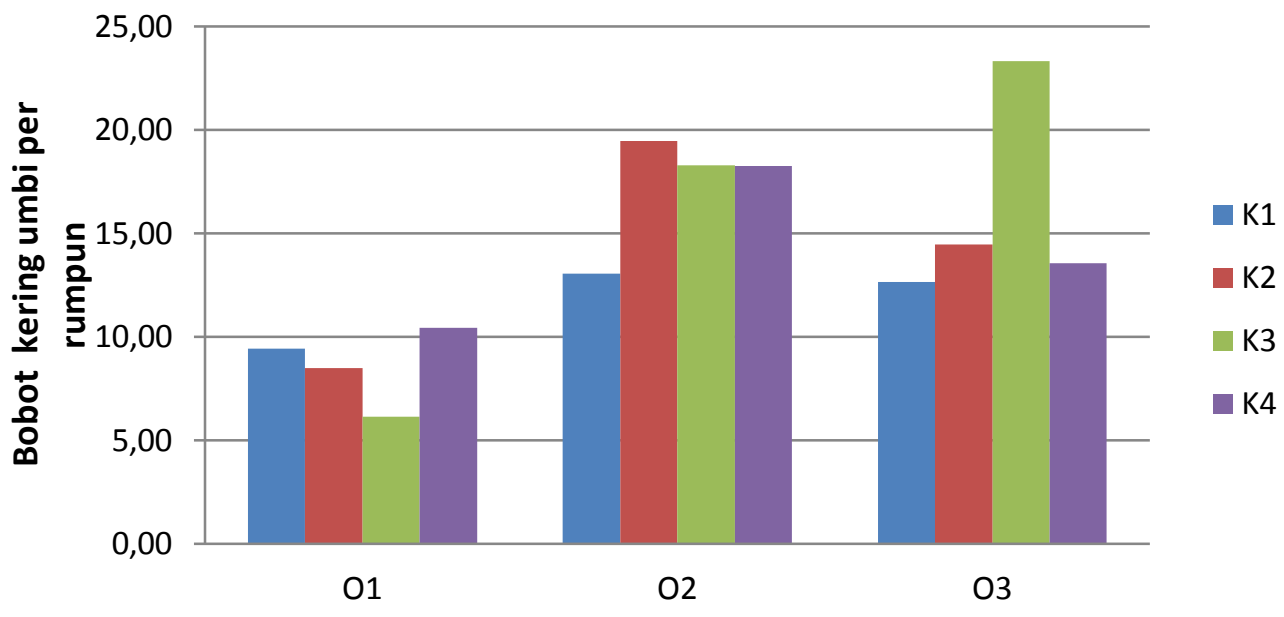

Perlakuan penambahan pupuk kandang dan NPK

(B)

Gambar 3. Parameter hasil tanaman A) Bobot segar umbi perumpun dan B) Bobot kering umbi perumpun dari penambahan pupuk kotoran ayam dan NPK secara meningkat.

Peningkatan maksimum bobot segar umbi dan bobot kering umbi terjadi pada tanaman umur 20 mst. Perlakuan O3K3 memiliki bobot segar umbi (62,90 g.rumpun $\left.{ }^{-1}\right)$ dan bobot kering umbi (23,31 g.rumpun ${ }^{-1}$ ) lebih tinggi dibandingkan perlakuan lainnya. Hal ini karena perlakuan ini merupakan komposisi yang mampu menyediakan unsur hara dalam jumlah cukup dan berimbang yang pada akhirnya berpengaruh terhadap pertumbuhan maupun hasil tanaman. Semakin meningkat jumlah daun tanaman maka hasil fotosintesis akan meningkat pula diiringi dengan bobot segar umbi dan bobot kering umbi yang lebih tinggi.

Pupuk kotoran ayam mampu menciptakan struktur tanah berpasir menjadi lebih baik dan dapat menahan air maupun unsur hara lebih banyak sehingga dapat diserap tanaman.

Demikian pula penambahan unsur NPK sangat mempengaruhi kesuburan tanah dan tanaman. Penyerapan unsur N, $\mathrm{P}$ dan K secara lebih baik akan meningkatkan jumlah akar dan jumlah umbi dimana pada akhirnya akan meningkatkan bobot segar umbi serta diiringi bobot kering umbi. Unsur N merupakan bahan penting dalam penyusun asam amino, amida, nukleotida dan nukleoprotein serta esensial untuk pembesaran dan pembelahan sel (Gardner dkk., 1991; Sari, dkk., 2015). Unsur P meningkatkan kandungan karbohidrat, pemanjangan akar dan meningkatkan jumlah dan ukuran umbi sehingga hasil tanaman meningkat (Sing dkk., 2000; Veneklaas dkk., 2012; Cocozza dkk., 2020). Unsur K berperan dalam membantu proses fotosintesis dimana senyawa organik diangkut ke umbi serta menghasilkan umbi yang berkualitas (Bybordi \& Malakouti, 2003).

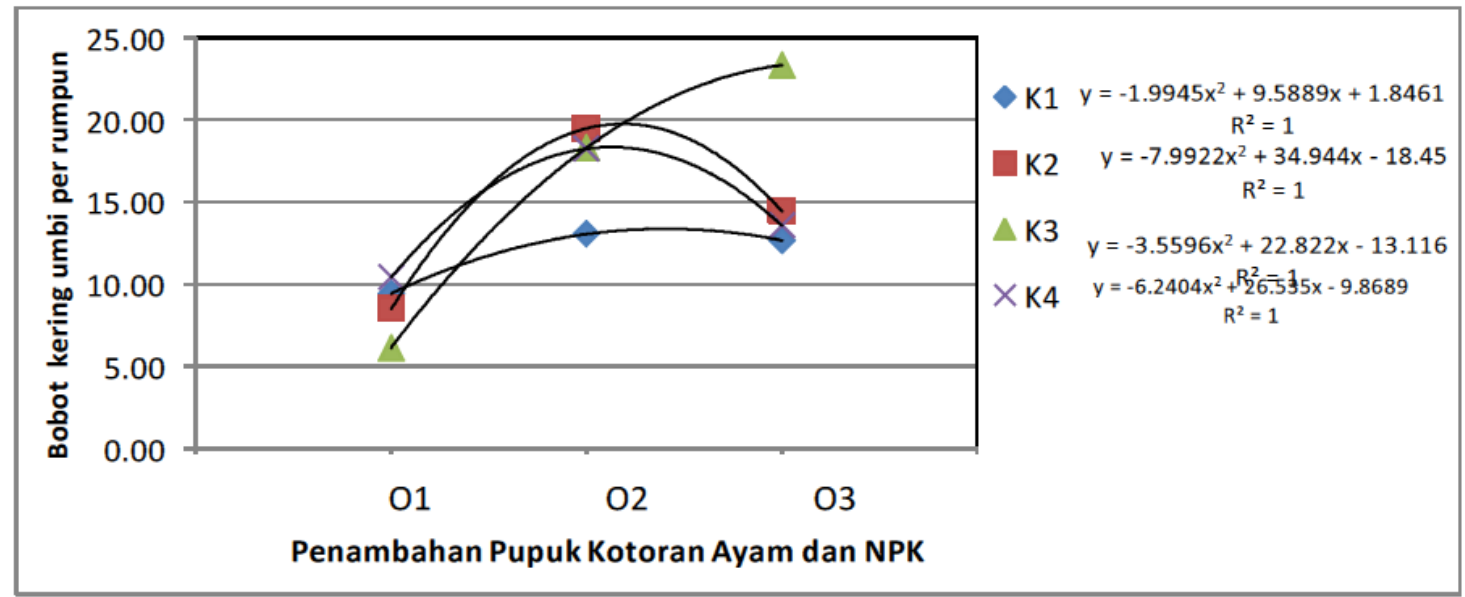

Gambar 4. Hubungan bobot kering umbi dengan perlakuan penambahan pupuk kotoran ayam dan NPK

Berdasarkan hasil penelitian ini menunjukkan bahwa penambahan pupuk kotoran ayam dan NPK berdasarkan bobot kering umbi per rumpun menghasilkan kurva kuadratik. Kurva kuadratik memiliki titik optimal yang dapat digunakan sebagai penyusun dosis rekomendasi pemupukan. Titik optimal penambahan takaran pupuk kotoran ayam dan NPK terdapat pada perlakuan 03K3 sebesar 23,31 g.rumpun ${ }^{-1}$ sedangkan takaran pupuk kotoran ayam dan NPK terkecil terdapat pada perlakuan 01K1 sebesar 6,15 g.rumpun ${ }^{-1}$. 


\section{Kelayakan ekonomi}

Teknologi inovasi guna meningkatkan produktivitas produksi pertanian membutuhkan setidaknya dua kelayakan yaitu kelayakan teknis dan kelayakan ekonomis. Secara teknis layak namun tidak efisien karena pemborosan maka inovasi tersebut sulit diterapkan masyarakat.

Tabel 2. Analisis biaya produksi, produksi, penerimaan dan keuntungan (pendapatan) usahatani bawang dayak pada tanah berpasir di Kalimantan Tengah

\begin{tabular}{|c|c|}
\hline Input produksi & Jumlah \\
\hline \multicolumn{2}{|l|}{ A. Biaya saprodi } \\
\hline 1. Bibit 25 kg/hax @ Rp. 25.000,- & $625.000,-$ \\
\hline 2. Pupuk Kandang 10.000 kg/ha x @ Rp.600,- & 6.000.000,- \\
\hline \multicolumn{2}{|l|}{ 3. Pupuk buatan : } \\
\hline - Urea (kg)200 kg x Rp. 8.000 & 1.600 .000 \\
\hline - SP 36 (kg)150 kg x Rp.10.000 & 1.500 .000 \\
\hline$-\mathrm{KCl}(\mathrm{kg}) 200 \mathrm{~kg} \times \mathrm{Rp} .8 .000$ & 1.600 .000 \\
\hline Total pupuk buatan(3) & 4.700 .000 \\
\hline \multicolumn{2}{|l|}{ 4. Tenaga kerja } \\
\hline - Pria (1 org x 120 hr x 50.000/hr ) & 6.000 .000 \\
\hline - Wanita(1 org x 120 hr x 50.000/hr) & 6.000 .000 \\
\hline Total tenaga kerja (4) & 12.000 .000 \\
\hline 5. Sewa Lahan (Rp/ha) & 1.000 .000 \\
\hline Total biaya sarana produksi $(A=1+2+3+4+5)$ & 24.325 .000 \\
\hline B. Total Produksi umbi Bawang $(\mathrm{kg})(5)$ & 7.000 \\
\hline \multicolumn{2}{|l|}{ C. Penerimaann (Total Produksi x harga/kg) } \\
\hline 7.000 kg x Rp. 20.000 & 140.000 .000 \\
\hline \multicolumn{2}{|l|}{ Catatan: harga per kg Rp.20.000 } \\
\hline D. Pendapatan atau Keuntungan $=(c-a)$ & 115.675 .000 \\
\hline E. $R / C$ rasio utk melihat efisiensi $(C / A)$ & 5,75 \\
\hline
\end{tabular}

Tabel 2 menggambarkan bahwa, penambahan komposisi pupuk kotoran ayam dan NPK ditinjau dari segi analisis usahanya memiliki Nilai R/C lebih dari satu $(5,75)$ artinya teknologi rakitan sangat efisien untuk dikembangkan. Nilai R/C 5,75 menunjukkan bahwa setiap seribu rupiah yang dikeluarkan untuk membiayai usaha menanam bawang akan mendapat penerimaan sebesar Rp. 5.755. Artinya keuntungan ekonomi mencapai lebih dari lima kali lipat.

\section{KESIMPULAN}

Komposisi pupuk kandang kotoran ayam sebesar 20 ton.ha-1 dan NPK sebesar 200 kg.ha-1 Urea +150 kg.ha-1 SP $36+200 \mathrm{~kg} \cdot \mathrm{ha}^{-1} \mathrm{KCl}$ memberikan hasil optimum untuk meningkatkan produktivitas tanaman bawang dayak pada tanah berpasir di Kalimantan Tengah. Hasil bobot umbi segar tertinggi yang dicapai sebesar 62,90 g.rumpun ${ }^{-1}$, sedangkan pada tanaman yang tidak diberi pupuk kotoran ayam dan NPK hasilnya hanya sebesar 19,86 g.rumpun ${ }^{-1}$. Komposisi optimum tersebut dapat meningkatkan jumlah daun, bobot segar umbi dan bobot kering umbi. Berdasarkan hasil analisis usahanya, komposisi optimal pupuk kandang kotoran ayam dan dan NPK dengan dosis tersebut memiliki layak secara ekonomi dan memberikan penerimaan lebih dari 5 kali lipat. Hal ini ditunjukkan oleh nilai R/C sebesar 5,75 hal ini menunjukkan bahwa hasil penelitian ini sangat efisien untuk dikembangkan.

\section{DAFTAR PUSTAKA}

Aliya, M. K., Alam, M., F, Islam, M.,S, Khndaker. S, M, A., T. (2007). Effect nitrogen and potassium level onyield and quality seed productionof union, Journal of Applied Sciences Research, 3(12), 1889-1899. http://www.aensiweb.com/old/jasr/jasr/2007/1889-1899.pdf

Al-juthery, H. W., \& Al-Shami, Q. M. (2019). The Effect of Fertigation with nano NPK fertilizers on some parameters of growth and yield of potato (Solanum tuberosum L.). AL-Qadisiyah Journal For Agriculture Sciences, 9(2), $225-232$. https://doi.org/10.1088/1755-1315/553/1/012010

Arwati, N., Wirjatmadi, B., Adriani, M., Meilanani, S., Winarni, D., \& Hartiningsih, S. (2018). The Effect of Dayak Onion Bulb-Stem (Eleutherine Palmifolia (L.,) Merr.) Extract on Blood Glucose Levels of Mouse Suffered Diabetes Mellitus. Health Notions, 2(3), 368-372. https://doi.org/10.33846/hn.v2i3.153

Atikah, T. A. (2020). Potensi bawang dayak untuk meningkatkan imunitas dan mencegah virus. Media cetak Kalteng Post, Edisi Rabu, 08 Juli 2020.

Bahtiar, A., \& Annisa, R. (2018). Effects of dayak onion bulbs (Eleutherine bulbosa (Mill.) Urb) on bone development of the hipoestrogen model rat. Pharmacog Journal, 10(2), 299-303. https://doi.org/10.5530/pj.2018.2.52 
Bybordi, A., \& Malakouti, M. J. (2003). Effects of Iron, Manganese, Zinc and Copper on Wheat Yield and Quality under Salin Condition. Olom-eAb Va Khak, 17(2), 48-59. https://www.sid.ir/en/Journal/ViewPaper.aspx?ID=4237

Candra, H. M. K. (2019). Pengaruh pemberian pupuk kandang kotoran ayam terhadap pertumbuhan anakan pekawai (Durio kutejensis) pada tanah podsolik merah kuning. Publikasi Informasi Pertanian, 15(29), $164-173$. http://jurnal.unka.ac.id/index.php/piper/article/download/334/393

Cocozza, C., Federico, B., Sara, P., Susanna, P., Cecilia, B., Cristina, G., ... \& Francesco, L. (2020). The excess of phosphorus in soil reduces physiological performances over time but enhances prompt recovery of salt-stressed Arundo donax plants. Plant Physiology and Biochemistry, 151, 556-565. https://doi.org/10.1016/j.plaphy.2020.04.011

Deanti, F. E., Wahyudi, W., \& Alatas, A. (2020). Pengaruh pemberian pupuk kotoran ayam dan pupuk tsp terhadap produksi tanaman mentimun (Cucumis sativus L.). Green swarnadwipa: jurnal pengembangan ilmu pertanian, 9(2), 213-220. https://www.ejournal.uniks.ac.id/index.php/GREEN/article/download/753/502

Fransira, I., Yanuhar, U., \& Maftuch, M. (2019). Potential of dayak onion (Eleutherine palmifolia (L) Merr) extract as antibacterial against pseudomonas fluorescens. The Journal of Experimental Life Science, 9(2), 76-80. http://dx.doi.org/10.21776/ub.jels.2019.009.02.03

Gardner, F. P., Pearce, R. B., \& Mitchell, R. L. (1985). Physiology of Crop Plants. The lowa State University Press. Ames, lowa 50010. USA. p. 82-84.

Gardner, F. P., Pearce, R. B., \& Mitchell, R. L. (1991). Physiology of Crop Plants (Fisiologi Tanaman Budidaya, alih bahasa oleh Susilo). Universitas Indonesia.

Ghaffoor, A., Jilani, M. S., Khaliq, G., \& Waseem, K. (2003). Effect of different NPK levels on the growth and yield of three onion (Allium cepa L.) varieties. Asian Journal of Plant Sciences, 2(3), $342-346$. http://jurnal.unsyiah.ac.id/TIPI/article/view/5976/6866

Harlita, T. D., \& Oedjijono, A. A. (2018). The antibacterial activity of dayak onion (Eleutherine palmifolia (L.) merr) towards pathogenic bacteria. Tropical life sciences research, 29(2), 39. https://dx.doi.org/10.21315\%2Ftlsr2018.29.2.4

Hilwa, W., Harahap, D. E., \& Zuhirsyan, M. (2020). Pemberian pupuk kotoran ayam dalam upaya rehabilitasi tanah ultisol desa janji yang terdegradasi. Agrica Ekstensia, 14(1), 75-80.

Iqbal, M., Linda, R., \& Mukarlina, M. (2020). Pengaruh kotoran ayam dan mikoriza glomus aggregatum terhadap pertumbuhan kedelai (Glycine max) pada tanah gambut. Protobiont, 9(1), 56-64. http://dx.doi.org/10.26418/protobiont.v9i1.40621

Jaya, B. (1994). Pengaruh dosis pupuk N dan P terhadap pertumbuhan dan hasil umbi bawang merah di dataran rendah madura. Buletin Penelitian Holtikultural, 26(3), 145-151.

Kamarudin, A. A., Esa, N. M., Saad, N., Sayuti, N. H., \& Razak, N. A. A. (2020). Heat assisted extraction of phenolic compounds from Eleutherine bulbosa (Mill.) bulb and its bioactive profiles using response surface methodology. Industrial Crops and Products, 144, 1-8. https://doi.org/10.1016/j.indcrop.2019.112064

Krestini, E. H., Susilawati, A., \& Hermanto, C. (2020). Effect of NPK fertilizer and microbial consortium to growth and production of garlic (Allium sativum L.). In BIO Web of Conferences (Vol. 20, p. 03010). EDP Sciences.

Kriswantoro, H., Safriyani, E., Lestaluhu, F. Y., \& Romza, E. (2020). Respon kacang tanah (arachis hypogaea I.) Terhadap dosis pupuk kotoran ayam pada jarak tanam yang berbeda. Agronitas, 2(1), 10-18.

Lestari, R. H. S., \& Palobo, F. (2019). Pengaruh dosis pupuk NPK terhadap pertumbuhan dan hasil bawang merah, kabupaten jayapura, papua. Ziraa'ah Majalah Ilmiah Pertanian, 44(2), 163-169. http://dx.doi.org/10.31602/zmip.v44i2.1782

Napitupulu, D \& Winarto, L. (2010). Pengaruh pemberian pupuk N dan K terhadap pertumbuhan dan produksi bawang merah. Jurnal Hortikultura, 20(1), 27-35.

Nugroho, W. A., \& Firmansyah, M. A. (2016). Pengaruh jenis dan dosis pupuk kandang terhadap pertumbuhan dan produksi bawang merah di lahan kering dataran rendah. In Seminar Nasional Inovasi Teknologi Pertanian Banjarbaru (pp. 906-913).

Nurcahyawati, D. G., Plumeriastuti, H., \& Maslachah, L. (2017). Protection of dayak onion tuber extract (Eleutherine Palmifolia) against kidney histopathological appearence of albino male rat strain wistar which was induced by alloxan. KnE Life Sciences, 702-711. https://doi.org/10.18502/kls.v3i6.1200

Poerwosusanta, H., Noor, Z., Mintaroem, K., Widjajanto, E., \& Ali, M. (2019). Extraction the dayak onion (Eleutherine sp): scientific based herbal medicine (oht) production protocol. Berkala Kedokteran, 15(2), $133-143$. http://dx.doi.org/10.20527/jbk.v15i2.7263

Purba, R. (2014). Applications of NPK phonska and KCl fertilizer for the growth and yield of shallots (Allium ascalonicum) in Serang, Banten. International Journal of Applied, 4(3), 197-203. http://www.ijastnet.com/journal/index/600

Pusat Studi Biofarmaka LPPM IPB dan Gagas Ulung. (2013). Sehat alami dengan herbal. Bogor.

Rambe, B. S., Ningsih, S. S., \& Gunawan, h. (2020). Pengaruh pemberian pupuk NPK mutiara dan pupuk organik cair GDM terhadap pertumbuhan dan produksi tanaman bawang merah (Allium ascalonicum). BERNAS Agricultural Research Journal, 15(2), 64-73. http://www.jurnal.una.ac.id/index.php/jb/article/view/773

Rosmarkam, A., \& Yuwono, N. W. (2002). Ilmu kesuburan tanah. Yogyakarta: Kanisius.

Salter, P. J., \& Williams, J. B. (1965). The influence of texture on the moisture characteristics of soils: II. Available-water capacity and moisture release characteristics. Journal of Soil Science, 16(2), 310-317. https://doi.org/ 10.1111/j.13652389.1965.tb01442.x 
Sari, R., Ratnasari, E., \& Fitrihidajati, H. (2015). Pemanfaatan limbah ternak kambing etawa sebagai bahan pupuk organik cair untuk budi daya baby corn. Jurusan Biologi, Fakultas Matematika dan Ilmu Pengetahuan Alam Universitas Negeri Surabaya. LenteraBio, 3(2), 143-149.

Sharma, R. P., Datt, N., \& Sharma, P. K. (2003). Combined application of nitrogen, phosphorus, potassium and farmyard manure in onion (Allium cepaL) under high hills, dry temperate condition of North-Western Himalayas. Indian Journal Of Agricultural Sciences, 73(4), 225-227. https://worldveg.tind.io/record/20466

Shereen, A., Ansari, R. U., Yasmin, S., Raza, S., Mumtaz, S., Khan, M. A., \& Mujtaba, S. M. (2007). Physiological responses of rice (Oryza sativa L.) to saline stress. Pak. J. Bot, 39(7), 2527-2534. http://www.pakbs.org/pjbot/PDFs/39(7)/PJB39(7)2527.pdf

Shireen, K. F., Pace, R. D., Mahboob, M., \& Khan, A. T. (2008). Effects of dietary vitamin E, C and soybean oil supplementation on antioxidant enzyme activities in liver and muscles of rats. Food and Chemical Toxicology, 46(10), 3290-3294. https://doi.org/10.1016/j.fct.2008.07.015

Singh, J. V., Kumar, A., \& Singh, C. (2000). Influence of phosphorus on growth and yield of onion (Allium cepa L.). Indian Journal of Agricultural Research, 34(1), 51-54. https://doi.org/10.3923/ajps.2003.342.346

Veneklaas, E. J., Lambers, H., Bragg, J., Finnegan, P. M., Lovelock, C. E., Plaxton, W. C., ... \& Raven, J. A. (2012). Opportunities for improving phosphorus-use efficiency in crop plants. New phytologist, 195(2), 306-320. https://doi.org/10.1111/j.1469-8137.2012.04190.x

Yuanita, I., Sunarti, D., Wahyuni, H. I., \& Suthama, N. (2019). Feeding dayak onion (Eleutherine palmifolia) extract and Lactobacillus acidophilusmixture on blood biochemicals, meat quality characteristics and growth performance in broiler chickens. Livestock Research for Rural Development, 31(9), 23-32. http://www.Irrd.org/Irrd31/9/yuanit31144.html 